\title{
PENGARUH BUDAYA ORGANISASI DAN ETOS KERJA TERHADAP KUALITAS PELAYANAN MAHASISWA
}

\author{
Yunita Indriany \\ Politeknik LP3I Jakarta \\ Yunitabasrie_81@yahoo.com
}

\begin{abstract}
Abstrak. Pengaruh budaya organisasi dan etos kerja terhadap kualitas layanan mahasiswa (LP3I Politeknik Studi Kasus di Jakarta, Kampus Cibinong). Penelitian ini bertujuan untuk seberapa besar pengaruh budaya organisasi, etos kerja pada tingkat kepuasan pelanggan. Metode pengambilan sampel yang digunakan adalah Proporsional random sampling. Sampel dalam penelitian ini mengikuti formula Slovin, atau sebanyak 80 siswa dan 21 staf karyawan. Data yang telah memenuhi uji validitas dan uji reliabilitas diproses lebih lanjut untuk menghasilkan persamaan regresi $\mathrm{Y}=\mathrm{X} 1+0,0250.457+0678$ $\mathrm{X}$, di mana Y adalah variabel kualitas layanan mahasiswa, budaya organisasi adalah variabel X1 dan $\mathrm{X} 2$ adalah variabel etos kerja

Pengujian hipotesis dengan menggunakan t-test Menunjukkan bahwa masing-masing variabel independen yang diteliti terbukti secara signifikan mempengaruhi variabel dependen secara parsial pada kualitas layanan mahasiswa. Kemudian melalui uji $\mathrm{F}$ dapat diketahui bahwa kedua variabel independen secara bersamaan Diperiksa menunjukkan ke Mempengaruhi kualitas variabel dependen layanan mahasiswa. Angka Adjusted R Square dari 0.697menunjukkan bahwa variabel Kepuasan 69,7\% Pelanggan dapat dijelaskan dengan dua variabel independen, sedangkan sisanya 30,3\% dijelaskan oleh variabel lain.
\end{abstract}

Kata Kunci: budaya organisasi, etika kerja, kualitas layanan mahasiswa

Abstract. The influence of organizational culture and work ethos against the quality of student services (LP3I Polytechnic Case Study in Jakarta, Campus Cibinong)

This study aims to how much influence organizational culture, work ethic on the level of customer satisfaction. The sampling method used is Proportionate random sampling. The sample in this study follows the formula of Slovin, or as many as 80 students and 21 staff employees. The data that have met the test of validity and reliability testing further processed to generate a regression equation of $Y=$ $X 1+0.0250 .457+0678 X 2$, where $Y$ is the variable quality of student services, organizational culture is a variable $X 1$ and $X 2$ are variables work ethic.

Hypothesis testing using t-test showed that each of the independent variables studied was shown to significantly affect the dependent variable partially on the quality of student services. Then through the $F$ test can be seen that the two independent variables were examined simultaneously shown to affect the dependent variable quality of student services. Figures Adjusted $R$ Square of 0.697menunjukkan that $69.7 \%$ Customer Satisfaction variables can be explained by the two independent variables, while the remaining $30.3 \%$ is explained by other variables.

Key words: Organizational culture, work ethic and quality of student services

Politeknik LP3I Kampus Cibinong juga berperan sebagai lembaga pendidikan tinggi yang bertanggung jawab dalam menghasilkan lulusannya yang berkompetensi serta responsif terhadap perkembangan/perubahan tuntutan dunia kerja.
Untuk menghasilkan mutu lulusan perguruan tinggi yang berkualitas tentunya tidak hanya perlu dilakukan kegiatan proses belajar mengajar di kelas antara dosen dengan mahasiswa, namun juga didukung oleh kegitan pendukung lainnya, seperti kegiatan administrasi 
di bagian Pendidikan, keuangan dan kemahasiswaan. Kelancaran dan kecepatan pelayanan di bagian administrasi tersebut sangat tergantung kepada sumber daya manusia yang dimiliki Lembaga Pendidikan Tinggi tersebut.

Budaya organisasi di LP3I Kampus Cibinong merupakan faktor yang sangat penting di dalam organisasi sehingga efektivitas organisasi dapat ditingkatkan dengan menciptakan budaya yang tepat dan dapat mendukung tercapainya tujuan organisasi. Pengaruh pemanfaatan budaya perusahaan di LP3I Kampus Cibinong adalah salah satu solusi dalam menghadapi tantangan yang kian kompleks. Bila budaya organisasi telah disepakati sebagai sebuah strategi perusahaan maka budaya organisasi dapat dijadikan alat untuk meningkatkan kinerja. Dengan adanya pemberdayaan budaya organisasi selain akan menghasilkan sumber daya manusia yang berkualitas, juga akan menjadi penentu sukses perusahaan. Sehingga budaya organisasi memiliki dampak yang berarti terhadap kinerja karyawan yang menentukan keberhasilan dan kegagalan perusahaan. sedangkan kinerja merupakan peranan yang sangat penting, karena tanpanya organisasi hanya merupakan sekumpulan aktivitas tanpa tujuan atau control tertentu. Dalam penelitian ini budaya organisasi dipahami sebagai seperangkat nilai, kepercayaan, dan pemahaman yang penting samasama dimiliki oleh para anggota yang berpengaruh terhadap pola kerja serta pola manajemen organisasi.

Pelayanan merupakan suatu kegiatan atau urutan kegiatan yang terjadi dalam interaksi langsung antara mahasiswa dengan pegawai pada bagian akademik pada Perguruan Tinggi dan menyediakan informasi kepada mahasiswa. Pelayanan sebagai usaha melayani kebutuhan mahasiswa agar proses belajar mengajar berjalan dengan baik, sedangkan melayani adalah membantu menyiapkan (mengurus) apa yang diperlukan oleh mahasiswa.

Namun pada kenyataaannya seringkali kualitas pelayanan terhadap mahasiswa belum dapat dilakukan secara maksimal, karena berbagai keterbatasan dan kendala yang ada, baik itu keterbatasan fasilitas dan sarana/prasarana kampus seperti masih minimnya tempat parkir yang tersedia, minimnya fasilitas buku-buku perpustakaan, minimnya toilet, minimnya kualitas mushola, minimnya keberadaan kantin, keterbatas jumlah petugas akademik, keterbatasan hot spot, dan lain sebagainya, sehingga tidak heran masih seringkali dijumpai berbagai keluhan dari para mahasiswa

Rendahnya kualitas tersebut, diduga disebabkan banyak faktor, diantaranya masih minimnya faktor fasilitas/sarana dan prasarana, masih lemahnya kualitas layanan karyawan karena lemahnya etos kerja mereka, lemahnya kepedulian, kesigapan dan keramahtamahan karyawan karena masih lemahnya penerapan budaya organisasi, lemahnya kualitas dosen yang mengajar dan masih banyak lagi kelemahan lainnya. Penulis menduga lemahnya kualitas pelayanan didominasi 2 faktor yaitu masih lemahnya etos kerja para karyawan serta lemahnya penerapan budaya organisasi.

Moeljono (2004) menyatakan bahwa budaya organisasi adalah sistem nilai-nilai yang diyakini oleh semua anggota organisasi dan yang dipelajari, diterapkan, serta dikembangkan secara berkesinambungan, berfungsi sebagai sistem perekat, dan dapat dijadikan acuan berperilaku dalam organisasi untuk mencapai tujuan perusahaan yang telah ditetapkan.

Sedangkan dalam konteks pengembangan sumber daya manusia, Eldridge dan Crombie dalam Wirawan (2007) menyatakan bahwa budaya organisasi sebagai "the unique configuration of norms, values, beliefs, ways of behaving and so on that characterize the manner in which groups and individuals combine to get things done".

Artinya budaya organisasi menunjukkan konfigurasi unik dari norma, nilai, kepercayaan, dan cara-cara berperilaku yang memberikan karakteristik cara kelompok dan individu bekerja sama untuk menyelesaikan tugasnya.

Meskipun terdapat banyak pengertian budaya organisasi yang dikemukakan oleh para ahli di bidang manajemen sumber daya manusia, namun semuanya memiliki kesamaan makna yang sama. Budaya organisasi menciptakan situasi dimana di dalamnya terdapat kesamaan cara pandang berdasarkan kesepakatan atas 
Yunita Indriany, Pengaruh Budaya Organisasi Dan Etos Kerja ...

keberlakuan nilai-nilai dalam organisasi yang harus dipelajari dan dipahami sebagai penuntun semua pihak dalam bersikap dan berperilaku untuk mencapai tujuan dan sasaran yang telah ditetapkan.

Menurut Pabundu (2004 : 2-7), Dimensi dan budaya Organisasi adalah : 1. Dimensi Karakteristik primer, yang terdiri atas indikator : 1.a. Inovasi, 1.b. Siap menghadapi resiko, 1.c. Orientasi orang, 1.d. Orientasi hasil dan tim, 1.e. Keagresipan, 1.f. Menetapkan nilai-nilai; 2. Langkah memperkuat budaya organisasi, yang terdiri atas indicator: 2.a. Melakukan pembinaan terhadap anggota, 2.b. Memberikan contoh teladan, 2.c. Membuat acara rutinitas dan 2.d Memberikan penilaian dan penghargaan.

Adapun ethos diartikan sebagai watak atau semangat fundamental suatu budaya, berbagai ungkapan yang menunjukkan kepercayaan, kebiasaan, atau perilaku suatu kelompok masyarakat. Jadi etos kerja berkaitan erat dengan budaya kerja. Sebagai dimensi budaya, keberadaan etos kerja dapat diukur dengan tinggi rendah, kuat (keras) atau lemah.

Menurut Chong dan Tai dalam Wirawan (2007) mengemukakan bahwa :

“.... etos kerja sebagai work ethic belief system pertahins to ideas that stress individualism/independence and the positive effect of work on individuals. Work is thus considered good in itself because it dignifies a person. Making personal effort to work hard will ensure success".

Etos kerja tersebut mengenai ide yang menekankan individualisme atau independensi dan pengaruh positif bekerja terhadap individu. Bekerja dianggap baik karena dapat meningkatkan derajat kehidupan serta status sosial seseorang. Berupaya bekerja keras akan memastikan kesuksesan

Sinamo (2005) menyatakan bahwa :

"...• etos kerja adalah seperangkat perilaku kerja positif yang berakar pada kedasaran yang kental, keyakinan yang fundamental, disertai komitmen yang total pada paradigma kerja yang integral. Istilah paradigma di sini berarti konsep utama tentang kerja itu sendiri yang mencakup idealisme yang mendasari, prinsip-prinsip yang mengatur, nilai-nilai yang menggerakkan, sikap-sikap yang dilahirkan, standar-standar yang hendak dicapai; termasuk karakter utama, pikiran dasar, kode etik, kode moral, dan kode perilaku bagi para pemeluknya”.

Menurut Alek. S. Nitisemito (2001: 75), dimensi dan indikator untuk mengetahui apakah etos kerja atau semangat kerja karyawan di perusahaan itu tinggi atau rendah adalah sebagai berikut: 1 . Dimensi sikap karyawan, terdiri atas indicator: 1.a) Fleksibilitas saat bekerja, yang terdiri atas indikator sebagai berikut; dan 1.b) Penyesuaian kerja; 2) Dimensi perasaan seorang karyawan, yang terdiri atas indikator sebagai berikut: 2.a) Penguasaan pekerjaan; dan 2.b) Senang bekerja; 3) Dimensi kesediaan karyawan dalam melaksanakan pekerjaanya, yang terdiri atas indikator sebagai berikut: 3.a) Kepatuhan bekerja; dan 3.b) Kemauan menyelesaikan pekerjaan; dan 4) Dimensi Keseriusan karyawan saat bekerja, yang terdiri atas indikator kesungguhan dalam bekerja

Kedua variable di atas diduga berpengaruh terhadap Kualitas Pelayanan Mahasiswa. Menurut Tjiptono (2004), kualitas merupakan kondisi dinamis yang berhubungan dengan produk, jasa, manusia, proses dan lingkungan yang memenuhi atau melebihi harapan. Dengan demikian kualitas pelayanan dapat diartikan sebagai upaya pemenuhan kebutuhan dan keinginan konsumen serta ketepatan penyampaiannya dalam mengimbangi harapan konsumen.

Lebih lanjut Zeithaml (1988) menyatakan bahwa kualitas pelayanan dapat didefinisikan sebagai penilaian pelanggan atas keunggulan atau keistimewaan suatu produk atau layanan secara menyeluruh. Kualitas pelayanan dapat diketahui dengan cara membandingkan persepsi konsumen atas pelayanan yang diterima dengan pelayanan yang sesungguhnya konsumen harapkan terhadap atribut-atribut pelayanan suatu perusahaan (Parasuraman et. al, 1988).

Kualitas pelayanan (service quality) dapat diukur dengan menggunakan lima dimensi. Kelima dimensi tersebut menurut Parasuraman, Zeithaml dan Berry (1985) dalam Tjiptono (2005) adalah: 1. Bukti langsung (tangibles), meliputi fasilitas 


\section{BIJAK}

Majalah Ilmiah Ilmu Administrasi

ISSN 1411-0830

fisik, perlengkapan, pegawai dan sarana komunikasi; $2 . \quad$ Reliabilitas (reliability), kemampuan untuk memberikan pelayanan yang dijanjikan dengan segera, akurat dan memuaskan; 3. Daya tanggap (responsiveness), yaitu keinginan untuk membantu para konsumen dan memberikan pelayan sebaik mungkin; 3. Jaminan / keyakinan (assurance), yaitu pengetahuan dan kesopansantunan para pegawai perusahaan serta kemampuan menumbuhkan rasa percaya para konsumennya kepada perusahaan; dan 4. Empati (empathy), meliputi kemudahaan melakukan hubungan, komunikasi yang baik, perhatian pribadi dan memahami kebutuhan para pelanggan.

\section{Kerangka Pemikiran}

Secara skematis kerangka Pemikiran Pengaruh Budaya Organisasi dan Etos Kerja terhadap kualitas pelayanan Akademik adalah ditunjukkan pada Gambar Paradigma berikut ini:

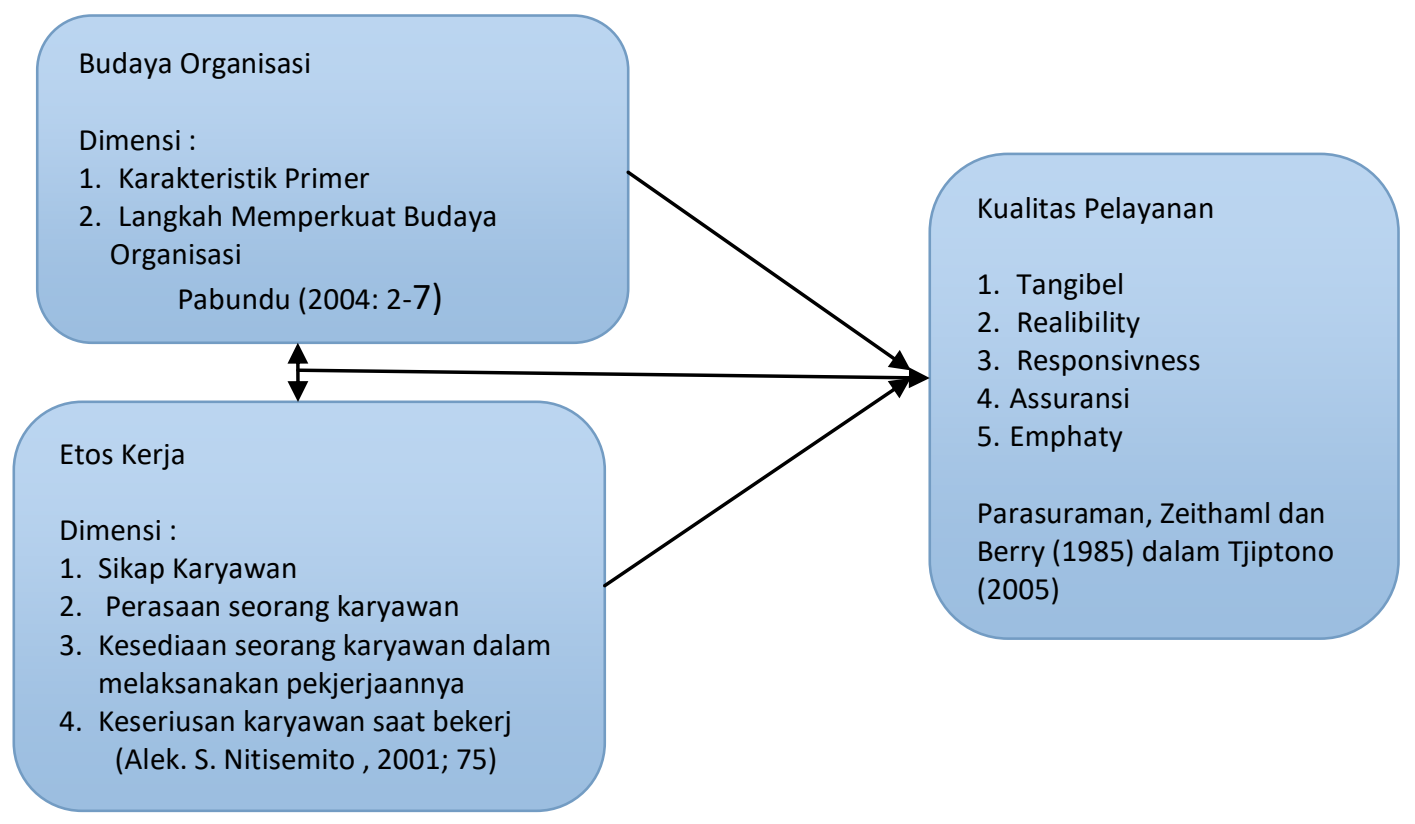

Gambar Paradigma : Pengaruh Budaya Organisasi dan Etos Kerja Terhadap Kualitas Pelayanan.

\section{Hipotesis}

Dengan kerangka pemikiran yang tersusun, maka hipotesis (jawaban sementara) yang diuji dalam penelitian ini diajukan dengan pernyataan (statement) berikut ini: 1. Budaya Organisasi berpengaruh secara signifikan terhadap ualitas Pelayanan Mahasiswa; 2. Etos Kerja berpengaruh secara signifikan terhadap Kualitas Pelayanan Mahasiswa; dan 3. Budaya Organisasi dan Etos Kerja berpengaruh secara signifikan terhadap Kualitas Pelayanan Mahasiswa.

\section{Metode penelitian}

\section{Pendekatan Penelitian}

Pendekatan yang digunakan dalam penelitian ini adalah survei. Menurut Nazir (2005) "survei adalah penelitian yang dilakukan untuk memperoleh fakta-fakta dan gejala-gejala yang ada serta mencari keterangan-keterangan secara faktual, baik tentang institusi sosial, ekonomi, atau politik dari suatu kelompok ataupun suatu daerah"

Jenis penelitian ini adalah deskriptif kuantitatif. Menurut Bungin (2005) penelitian deskriptif kuantitatif adalah penelitian yang menggambarkan, menjelaskan, atau meringkaskan berbagai kondisi, situasi, fenomena menurut kejadian sebagaimana adanya.

Adapun sifat penelitian ini adalah penelitian penjelasan (explanatory), yaitu suatu 
Yunita Indriany , Pengaruh Budaya Organisasi Dan Etos Kerja ...

penelitian yang menguraikan dan menjelaskan fenomena yang terjadi di objek penelitian.

\section{Operasionalisasi Variabel}

Operasionalisasi variable dari penelitian yang diangkat penulis terdiri dari Variabel Budaya Organisasi (X1) dan variabel Etos Kerja (X2) sebagai variabel yang memengaruhi atau disebut juga sebagai variabel penyebab, atau sering disebut spebagai variabel bebas atau independent variable $(\mathrm{X})$, serta variabel Kualitas Pelayanan sebagai yang dipengaruhi atau dependent variable.

Dalam Operasionalisasi Variabel tersebut berisi Kisi-kisi Variabel Penelitian yang memuat deskripsi dimensi (subvariabel), setiap dimensi dirumuskan indikatornya untuk kemudian menjadi item angket (quisionery).

Tabel Kisi-Kisi Variabel

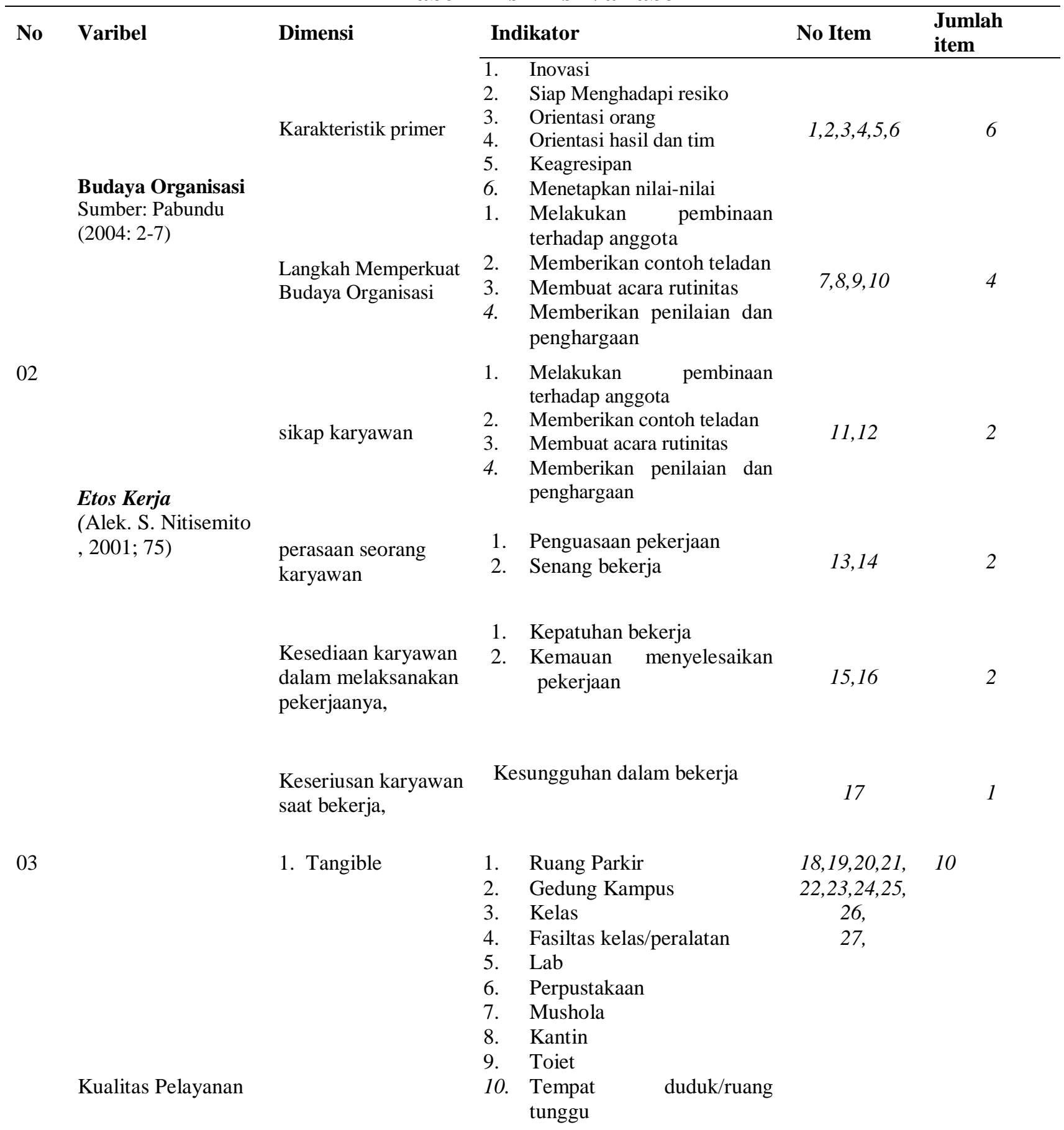




\begin{tabular}{|c|c|c|c|c|c|}
\hline \multirow[t]{5}{*}{ No } & Varibel & Dimensi & Indikator & No Item & $\begin{array}{l}\text { Jumlah } \\
\text { item }\end{array}$ \\
\hline & $\begin{array}{l}\text { Parasuraman, } \\
\text { Zeithaml dan Berry } \\
\text { (1985) dalam } \\
\text { Tjiptono (2005) }\end{array}$ & $\begin{array}{l}\text { 2. Kehandalan } \\
\text { (reliability) }\end{array}$ & $\begin{array}{ll}\text { 1. } & \begin{array}{l}\text { Kualitas Kemampuan } \\
\text { (kompetensi) Dosen Dalam }\end{array} \\
\text { Penyampaian Materi } \\
\text { Kuliah. } \\
\text { 2. } \quad \begin{array}{l}\text { Kualitas kemampuan } \\
\text { (kompetensi) karyawan }\end{array}\end{array}$ & 28,29 & 2 \\
\hline & & $\begin{array}{l}\text { 3. Daya tanggap } \\
\text { (responsiveness) }\end{array}$ & $\begin{array}{l}\text { 1. Kecepatan karyawan dalam } \\
\text { merespon keluhan } \\
\text { mahasiswa } \\
\text { 2. Kecepatan/kesigapan } \\
\text { Karyawan dalam Pelayanan } \\
\text { administrasi kemahsiswaan }\end{array}$ & 30,31 & 2 \\
\hline & & $\begin{array}{l}\text { 4. Jaminan } \\
\text { (assurance) }\end{array}$ & $\begin{array}{ll}\text { 1. } & \begin{array}{l}\text { Kemananan fisik } \\
\text { (lingkungan kampus), }\end{array} \\
\text { financial dan Kerahasiaan } \\
\text { 2. Kredibilitas Dosen } \\
\text { 3. Kredibilitas manajemen } \\
\text { pendidikan } \\
\text { 4. Kredibilitas Pengetahuan } \\
\text { dan keterampilan Karyawan } \\
\text { dalam Pelayanan } \\
\text { 5. Reputasi Lembaga }\end{array}$ & $\begin{array}{c}32,33,34,35 \\
36\end{array}$ & 5 \\
\hline & & 5. Empati (emphaty) & $\begin{array}{l}\text { 1. Komunikasi Pelayanan } \\
\text { 2. Pemahaman Kebutuhan } \\
\text { Pelanggan } \\
\text { 3. Keramahan, Perhatian, } \\
\text { Sopan santun Dan Respek } \\
\text { Karyawan }\end{array}$ & $37,38,39$ & 3 \\
\hline
\end{tabular}

Jenis Data dan Teknik Pengumpulan Data

Teknik Pengumpulan Data dilakukan dalam beberapa tahap sebagai berikut adalah data primer

meliputi: Observasi (pengamatan langsung di lokasi penelitian) dan kuesioner

\section{Populasi, Sample, dan Teknik Penarikan Sample}

\section{Populasi}

Populasi adalah keseluruhan unit atau individu dalam ruang lingkup yang ingin diteliti (Sugiarto, 2001: 2). Identifikasi populasi merupakan langkah awal dalam penelitian yang bertujuan untuk mengetahui siapa yang menjadi responden. Sedangkan menurut (Ferdinand, 2006), populasi adalah gabungan dari seluruh elemen yang berbentuk peristiwa, hal atau orang yang memiliki karakteristik yang serupa yang menjadi pusat perhatian seorang peneliti.

Adapun populasi dalam penelitian ini adalah 21 orang karyawan dan 100 orang mahasiswa.

\section{Sample}

Sampel adalah sebagian anggota dari populasi yang dipilih dengan menggunakan prosedur tertentu sehingga diharapkan dapat mewakili populasinya, sedangkan banyaknya anggota suatu sampel disebut ukuran sampel (Sugiarto, 2001: 2).

Sedangkan menurut (Ferdinand, 2006), sampel adalah subset dari populasi, terdiri dari beberapa anggota populasi). Pengambilan sampel dilakukan dengan pertimbangan bahwa populasi yang ada sangat besar jumlahnya, sehingga tidak memungkinkan untuk meneliti seluruh populasi 
Yunita Indriany, Pengaruh Budaya Organisasi Dan Etos Kerja ...

yang ada, sehingga dibentuk sebuah perwakilan populasi.

\section{Teknik Pengambilan Sampel}

Teknik pengambilan sample dilakukan dengan maksud agar kesimpulan statistik mengandung kebenaran, sehingga sampel yang dipilih sebagai landasan penyimpulan harus mewakili atau representatif untuk populasinya. Salah satu cara terbaik untuk memperoleh sampel semacam itu adalah teknik random sampling. Adapun dasar pokok dari random sampling adalah bahwa semua anggota populasi mempunyai peluang yang sama untuk dimasukkan sebagai anggota sampel. Dalam penelitian ini peneliti menggunakan teknik pengambilan sample secara "Proportionate Random Sampling”, yaitu suatu teknik pengambilan sampling dimana populasi yang ada tidak homogen dan berstrata secara proporsional (Sugiyono, 2009).

Untuk menentukan ukuran sampel dari suatu populasi dapat digunakan rumus slovin (1960) yang dikutip sevilla (1994) sebagai berikut (Umar : 1997)

$$
\mathrm{n}=\frac{\mathrm{N}}{1+N e^{2}}
$$

Keterangan :

$$
\begin{aligned}
& \mathrm{n}=\text { Ukuran Sampel } \\
& \mathrm{N}=\text { Ukuran Populasi } \\
& \mathrm{e}=\text { Persen kelonggaran } \\
& \text { ketidaktelitian }
\end{aligned}
$$

Mengingat populasi penelitian terdiri atas 21 orang karyawan dan 100 orang mahasiswa (N), maka jumlah sample yang akan diambil terdiri dari 2 jenis, yaitu sample karyawan dan sample mahasiswa. Untuk sample karyawan, jumlahnya diambil semua yaitu sebanyak 21 orang, karena termasuk sample jenuh, sedangkan untuk sample mahasiswa, diambil samplenya dengan tingkat kesalahan (e) $5 \%$ atau sebesar 0,05 yaitu sebanyak 80 orang mahasiswa dari 100 orang populasi mahasiswa.

\section{Teknik Analisis Data}

Dalam penelitian ini data yang dikumpulkan meliputi data kuantitatif maupun data kualitatif. Data kualitatif

\section{Uji Keabsahan Data}

Setelah data terkumpul, selanjutnya akan dilakukan uji keabsahan data dengan Uji

Validitas, Uji Reliabilitas,

Selanjutnya dalam pengolahan data, perlu dilakukan uji persyaratan analisis mencakup: Uji Normalitas, Uji Multikolinieritas, Uji Autokorelasi, dan Uji Heterokedastisitas, Analisis Regresi Linear Berganda, Uji statistik $t$, Uji statistik F, Korelasi Product Moment dan Koefisien Determinasi.

\section{Hasil Penelitian Deskripsi Responden}

Responden dalam penelitian ini adalah semua mahasiswa Politeknik LP3I Jakarta kampus Cibinong. Jumlah mahasiswa yang dipilih sebagai responden sebanyak 80 orang dengan identitas sebagai berikut : usia, fakultas dan semester: a. Usia Responden. Usia responden relative homogen dengan kisaran umur antara 18 s/d 20 tahun untuk responden mahasisswa; b. Konsentrasi, Penggolongan responden menurut tingkat pendidikannya dikelompokkan dalam tabel berikut ini

Tabel Distribusi Responden mahasiswa dan karyawan

\begin{tabular}{lccc}
\hline Responden & Jumlah & Frekuensi & $\begin{array}{l}\text { Prosentase } \\
(\boldsymbol{\%})\end{array}$ \\
\hline 1. Mahasiswa (Jurusan Administrasi & 100 & 80 & 79,2 \\
Bisnis) & $\mathbf{2 1}$ & $\mathbf{2 1}$ & $\mathbf{2 0 , 8}$ \\
2. Karyawan & $\mathbf{1 2 1}$ & $\mathbf{1 0 1}$ & $\mathbf{1 0 0}$ \\
\hline
\end{tabular}

Sumber : Data Primer yang diolah, 2014 


\section{BIJAK}

Majalah Ilmiah Ilmu Administrasi

ISSN 1411-0830

\section{Uji Validitas dan Uji Reliabilitas}

Uji Validitas

Uji validitas digunakan untuk mengukur sah atau tidak sahnya suatu kuesioner. Dasar pengambilan keputusan yang digunakan adalah melakukan uji signifikasi dengan membandingkan nilai $r$ hitung dengan $r$ tabel. Untuk sampel sejumlah 80 buah nilai $\mathrm{r}$ tabel $=$ untuk $\alpha=5 \%=0,196$. Uji ini dilakukan manakala butir pertanyaan lebih dari 1 . Pengambilan keputusan uji validitas : a. Bila nilai $r$ hitung $>r$ tabel, maka item pertanyaan valid; dan Bila nilai $r$ hitung $<r$ tabel, maka item pertanyaan tidak valid.

Pengujian validitas selengkapnya dapat dilihat pada tabel berikut ini

\section{Tabel Uji Validitas Variabel Budaya Organisasi}

\section{Correlations}

\begin{tabular}{|c|c|c|}
\hline & & Tot_Budaya_Organ \\
\hline \multirow[t]{3}{*}{ Budaya_Organisasi 1} & Pearson Correlation & $.481^{* * *}$ \\
\hline & Sig. (1-tailed) & .000 \\
\hline & $\mathrm{N}$ & 21 \\
\hline \multirow{3}{*}{ Budaya_Organisasi 2} & Pearson Correlation & $.314^{* *}$ \\
\hline & Sig. (1-tailed) & .000 \\
\hline & $\mathrm{N}$ & 21 \\
\hline \multirow{3}{*}{ Budaya_Organisasi 3} & Pearson Correlation & $.578^{* *}$ \\
\hline & Sig. (1-tailed) & .000 \\
\hline & $\mathrm{N}$ & 21 \\
\hline \multirow{3}{*}{ Budaya_Organisasi 4} & Pearson Correlation & $.443^{* *}$ \\
\hline & Sig. (1-tailed) & .000 \\
\hline & $\mathrm{N}$ & 21 \\
\hline \multirow[t]{3}{*}{ Budaya_Organisasi 5} & Pearson Correlation & $.377^{* *}$ \\
\hline & Sig. (1-tailed) & .000 \\
\hline & $\mathrm{N}$ & 21 \\
\hline \multirow[t]{3}{*}{ Budaya_Organisasi 6} & Pearson Correlation & $.374^{* *}$ \\
\hline & Sig. (1-tailed) & .002 \\
\hline & $\mathrm{N}$ & 21 \\
\hline \multirow[t]{3}{*}{ Budaya_Organisasi 7} & Pearson Correlation & $.404^{* *}$ \\
\hline & Sig. (1-tailed) & .000 \\
\hline & $\mathrm{N}$ & 21 \\
\hline \multirow[t]{3}{*}{ Budaya_Organisasi 8} & Pearson Correlation & $.378^{* *}$ \\
\hline & Sig. (1-tailed) & .000 \\
\hline & $\mathrm{N}$ & 21 \\
\hline \multirow[t]{3}{*}{ Budaya_Organisasi 9} & Pearson Correlation & $.555^{* *}$ \\
\hline & Sig. (1-tailed) & .000 \\
\hline & $\mathrm{N}$ & 21 \\
\hline Budaya_Organisasi 10 & Pearson Correlation & $.552^{* *}$ \\
\hline
\end{tabular}


Yunita Indriany, Pengaruh Budaya Organisasi Dan Etos Kerja ...

\section{Correlations}

\begin{tabular}{lll} 
& Sig. (1-tailed) & .000 \\
Tot_Budaya_Organisasi & $\mathrm{N}$ & 21 \\
& Pearson Correlation & 1 \\
& Sig. (1-tailed) & .000 \\
& $\mathrm{~N}$ & 21 \\
\hline
\end{tabular}

**. Correlation is significant at the 0.01 level (1-tailed).

*. Correlation is significant at the 0.05 level (1-tailed).

Sumber : Data primer yang diolah, 2014

\begin{tabular}{|c|c|c|}
\hline \multicolumn{3}{|l|}{ Correlations } \\
\hline & & Tot_Etos_Kerja \\
\hline \multirow[t]{3}{*}{ Etos_Kerjai 1} & Pearson Correlation & $.851^{* * *}$ \\
\hline & Sig. (1-tailed) & .000 \\
\hline & $\mathrm{N}$ & 21 \\
\hline \multirow[t]{3}{*}{ Etos_Kerjai 2} & Pearson Correlation & $.886^{* *}$ \\
\hline & Sig. (1-tailed) & .000 \\
\hline & $\mathrm{N}$ & 21 \\
\hline \multirow[t]{3}{*}{ Etos_Kerjai 3} & Pearson Correlation & $.852^{* *}$ \\
\hline & Sig. (1-tailed) & .000 \\
\hline & $\mathrm{N}$ & 21 \\
\hline \multirow[t]{3}{*}{ Etos_Kerjai 4} & Pearson Correlation & $.813^{* *}$ \\
\hline & Sig. (1-tailed) & .000 \\
\hline & $\mathrm{N}$ & 21 \\
\hline \multirow[t]{3}{*}{ Etos_Kerjai 5} & Pearson Correlation & $.816^{* *}$ \\
\hline & Sig. (1-tailed) & .000 \\
\hline & $\mathrm{N}$ & 21 \\
\hline \multirow[t]{3}{*}{ Etos_Kerjai 6} & Pearson Correlation & $.374^{* *}$ \\
\hline & Sig. (1-tailed) & .002 \\
\hline & $\mathrm{N}$ & 21 \\
\hline \multirow[t]{3}{*}{ Etos__Kerjai 7} & Pearson Correlation & $.404^{* *}$ \\
\hline & Sig. (1-tailed) & .000 \\
\hline & $\mathrm{N}$ & 21 \\
\hline \multirow[t]{3}{*}{ Tot_Etos_Kerja } & Pearson Correlation & 1 \\
\hline & Sig. (1-tailed) & .000 \\
\hline & $\mathrm{N}$ & 21 \\
\hline
\end{tabular}

**. Correlation is significant at the 0.01 level (1-tailed).

*. Correlation is significant at the 0.05 level (1-tailed).

Sumber : Data primer yang diolah, 2014

\section{Correlation}

Tabel Uji Variabel Kualitas Pelayanan

\begin{tabular}{llr}
\hline & & $\begin{array}{c}\text { Tot_Kualitas_Pelayan } \\
\text { an }\end{array}$ \\
\hline Kualitas_Pelayanan 1 & Pearson Correlation & $.480^{* * *}$ \\
& Sig. (1-tailed) & .000 \\
& N & 80
\end{tabular}




\section{BIJAK}

Majalah Ilmiah Ilmu Administrasi

ISSN 1411-0830

\begin{tabular}{|c|c|c|}
\hline & & $\begin{array}{c}\text { Tot_Kualitas_Pelayan } \\
\text { an }\end{array}$ \\
\hline \multirow[t]{3}{*}{ Kualitas_Pelayanan 2} & Pearson Correlation & $.313^{* * *}$ \\
\hline & Sig. (1-tailed) & .000 \\
\hline & $\mathrm{N}$ & 80 \\
\hline \multirow[t]{3}{*}{ Kualitas_Pelayanan 3} & Pearson Correlation & $.577^{* *}$ \\
\hline & Sig. (1-tailed) & .000 \\
\hline & $\mathrm{N}$ & 80 \\
\hline \multirow[t]{3}{*}{ Kualitas_Pelayanan 3} & Pearson Correlation & $.442^{* *}$ \\
\hline & Sig. (1-tailed) & .000 \\
\hline & $\mathrm{N}$ & 80 \\
\hline \multirow[t]{3}{*}{ Kualitas_Pelayanan 5} & Pearson Correlation & $.376^{* *}$ \\
\hline & Sig. (1-tailed) & .000 \\
\hline & $\mathrm{N}$ & 80 \\
\hline \multirow[t]{3}{*}{ Kualitas_Pelayanan 6} & Pearson Correlation & $.373^{* *}$ \\
\hline & Sig. (1-tailed) & .002 \\
\hline & $\mathrm{N}$ & 800 \\
\hline \multirow[t]{3}{*}{ Kualitas_Pelayanan 7} & Pearson Correlation & $.403^{* *}$ \\
\hline & Sig. (1-tailed) & .000 \\
\hline & $\mathrm{N}$ & 80 \\
\hline \multirow[t]{3}{*}{ Kualitas_Pelayanan 8} & Pearson Correlation & $.377^{* *}$ \\
\hline & Sig. (1-tailed) & .000 \\
\hline & $\mathrm{N}$ & 80 \\
\hline \multirow[t]{3}{*}{ Kualitas_Pelayanan 9} & Pearson Correlation & $.556^{* *}$ \\
\hline & Sig. (1-tailed) & .000 \\
\hline & $\mathrm{N}$ & 80 \\
\hline \multirow[t]{3}{*}{ Kualitas_Pelayanan 10} & Pearson Correlation & $.551^{* *}$ \\
\hline & Sig. (1-tailed) & .000 \\
\hline & $\mathrm{N}$ & 80 \\
\hline \multirow[t]{3}{*}{ Kualitas_Pelayanan 11} & Pearson Correlation & $.477^{* *}$ \\
\hline & Sig. (1-tailed) & .000 \\
\hline & $\mathrm{N}$ & 80 \\
\hline \multirow[t]{3}{*}{ Kualitas_Pelayanan 12} & Pearson Correlation & $.529^{* * *}$ \\
\hline & Sig. (1-tailed) & .80 \\
\hline & $\mathrm{N}$ & 80 \\
\hline \multirow[t]{3}{*}{ Kualitas_Pelayanan 13} & Pearson Correlation & $.436^{* *}$ \\
\hline & Sig. (1-tailed) & .000 \\
\hline & $\mathrm{N}$ & 80 \\
\hline \multirow[t]{3}{*}{ Kualitas_Pelayanan 14} & Pearson Correlation & $.400^{* *}$ \\
\hline & Sig. (1-tailed) & .000 \\
\hline & $\mathrm{N}$ & 80 \\
\hline \multirow[t]{3}{*}{ Kualitas_Pelayanan 15} & Pearson Correlation & $.482^{* *}$ \\
\hline & Sig. (1-tailed) & .000 \\
\hline & $\mathrm{N}$ & 80 \\
\hline \multirow[t]{3}{*}{ Kualitas_Pelayanan 16} & Pearson Correlation & $.679^{* *}$ \\
\hline & Sig. (1-tailed) & .000 \\
\hline & $\mathrm{N}$ & 80 \\
\hline \multirow[t]{3}{*}{ Kualitas_Pelayanan 17} & Pearson Correlation & $.534^{* *}$ \\
\hline & Sig. (1-tailed) & .80 \\
\hline & $\mathrm{N}$ & 80 \\
\hline
\end{tabular}


Yunita Indriany, Pengaruh Budaya Organisasi Dan Etos Kerja ...

\begin{tabular}{|c|c|c|}
\hline & & $\begin{array}{c}\text { Tot_Kualitas_Pelayan } \\
\text { an }\end{array}$ \\
\hline \multirow[t]{3}{*}{ Kualitas_Pelayanan 18} & Pearson Correlation & $.582^{* *}$ \\
\hline & Sig. (1-tailed) & .000 \\
\hline & $\mathrm{N}$ & 80 \\
\hline \multirow[t]{3}{*}{ Kualitas_Pelayanan 19} & Pearson Correlation & $.700^{* * *}$ \\
\hline & Sig. (1-tailed) & .000 \\
\hline & $\mathrm{N}$ & 80 \\
\hline \multirow[t]{3}{*}{ Kualitas_Pelayanan 20} & Pearson Correlation & $.547^{* *}$ \\
\hline & Sig. (1-tailed) & .000 \\
\hline & $\mathrm{N}$ & 80 \\
\hline \multirow[t]{3}{*}{ Kualitas_Pelayanan 21} & Pearson Correlation & $.672^{* * *}$ \\
\hline & Sig. (1-tailed) & .000 \\
\hline & $\mathrm{N}$ & 80 \\
\hline \multirow[t]{3}{*}{ Kualitas_Pelayanan 22} & Pearson Correlation & $.663^{* *}$ \\
\hline & Sig. (1-tailed) & .000 \\
\hline & $\mathrm{N}$ & 80 \\
\hline \multirow[t]{3}{*}{ Tot_Kualitas_Pelayanan } & Pearson Correlation & 1 \\
\hline & Sig. (1-tailed) & .000 \\
\hline & $\mathrm{N}$ & 80 \\
\hline
\end{tabular}

Dari hasil pengolahan data di atas terlihat dengan jelas bahwa dapat dijelaskan nilai $\mathrm{r}$ hitung lebih besar dari nilai $\mathrm{r}$ kritis 0.3 , dengan demikian dapat disimpulkan bahwa semua item dalam indikator variabel budaya organisasi, etos kerja dan kualitas pelayanan adalah valid.

\section{Uji Reliabilitas}

Uji reliabilitas digunakan untuk mengukur konsistensi dari suatu variabel. Butir pertanyaan dalam variabel dikatakan reliabel atau terpercaya apabila jawaban responden adalah konsisten atau stabil dari waktu ke waktu. Suatu konstruk atau variabel dikatakan reliabel jika memberikan nilai Cronbach Alpha $\geq 0,60$. Adapun hasil uji reliabilitas variabel kualitas pelayanan dan nilai pelanggan terhadap kepuasan pelanggan dapat dilihat pada tabel berikut ini.

\section{Hasil Uji Reliabilitas}

Tabel Reliability Statistics of Budaya Orrganisasi

\section{Tabel Reliability Statistics of Etos Kerja}

\begin{tabular}{ll}
\hline Cronbach's Alpha & N of Items \\
\hline .867 & 7 \\
\hline Sumber : Data primer yang diolah, & 2014
\end{tabular}


Tabel Reliability Statistics of Kualitas Pelayanan

\begin{tabular}{ll}
\hline Cronbach's Alpha & N of Items \\
\hline .785 & 22 \\
\hline Sumber : Data primer yang diolah, 2014
\end{tabular}

Tabel Tabel Rangkuman Hasil uji Realibility

\begin{tabular}{lll}
\hline Variabel & Nilai Alpha & Keputusan \\
\hline Budaya Organisasi & 0.927 & Reliabel \\
Etos Kerja & 0.867 & Reliabel \\
Kualitas Pelayanan & 0.785 & Reliabel \\
\hline
\end{tabular}

Sumber : Data primer yang diolah, 2014

Berdasarkan tabel diatas dapat diketahui bahwa masing-masing variabel antara variabel Budaya Organisasi, Etos Kerja, dan Kualitas Pelayanan, ternyata diperoleh nilai Cronbach Alpha $\geq 0,60$. Dengan demikian, maka hasil uji reabilitas terhadap keseluruhan variabel adalah reliabel.

\section{Analisis Kualitatif}

Variabel Kualitas Budaya Organisasi (X1)

Analisis kualitatif untuk pengukuran variabel Budaya Organisasi dapat dilihat pada Tabel berikut

Tabel Tanggapan Responden Terhadap Budaya Organisasi

\begin{tabular}{|c|c|c|c|c|c|c|c|}
\hline No & Indikator & SS & $\mathbf{S}$ & CS & TS & STS & Skor \\
\hline 1 & Mampu menumbuhkan iklim Inovasi & 1 & 17 & 2 & 1 & 0 & 3.86 \\
\hline 2 & $\begin{array}{l}\text { Mampu menumbuhkan budaya siap Menghadapi } \\
\text { resiko }\end{array}$ & 3 & 13 & 4 & 1 & 0 & 3.86 \\
\hline 3 & $\begin{array}{l}\text { Mampu menumbuhkan budaya untuk senantiasa } \\
\text { berorientasi kepada orang }\end{array}$ & 3 & 11 & 6 & 1 & 0 & 3.76 \\
\hline 4 & $\begin{array}{l}\text { Mampu menumbuhkan budaya untuk senantiasa } \\
\text { berorientasi kepada hasil dan tim }\end{array}$ & 1 & 10 & 10 & 0 & 0 & 3.57 \\
\hline 5 & $\begin{array}{l}\text { Mampu menumbuhkan untuk senantiasa agresip } \\
\text { dalam menyelesaikan masalah }\end{array}$ & 1 & 12 & 8 & 0 & 0 & 3.67 \\
\hline 6 & Berorientasi kepada penilaian & 2 & 15 & 4 & 0 & 0 & 3.90 \\
\hline 7 & Melakukan pembinaan terhadap anggota & 1 & 16 & 4 & 0 & 0 & 3.86 \\
\hline 8 & Memberikan contoh teladan & 0 & 13 & 8 & 0 & 0 & 3.62 \\
\hline 9 & Membuat acara rutinitas & 2 & 3 & 16 & 0 & 0 & 3.33 \\
\hline 10 & $\begin{array}{l}\text { Memberikan penilaian dan penghargaan } \\
\text { Rata-rata }\end{array}$ & 1 & 1 & 11 & 8 & 0 & $\begin{array}{l}2.76 \\
3.61\end{array}$ \\
\hline
\end{tabular}

Sumber : Data primer yang diolah

Berdasarkan tabel 4.1 diatas diketahui bahwa skor jawaban responden untuk variable kualitas pelayanan adalah 3.61 berada pada kategori cukup setuju $(3,00-4,00)$. Hal ini mengindikasikan bahwa responden menilai bahwa budaya organisasi cukup baik menumbuhkan hal-hal yang positif

\section{Variabel Etos Kerja (X2)}

Analisis kualitatif untuk pengukuran variabel Budaya Organisasi dapat dilihat pada Tabel berikut : 
Yunita Indriany, Pengaruh Budaya Organisasi Dan Etos Kerja ...

Tabel Tanggapan Responden Terhadap Etos Kerja

\begin{tabular}{llcccccc}
\hline No & Indikator & SS & S & CS & TS & STS & Skor \\
\hline $\mathbf{1}$ & Mampu melakukan pembinaan terhadap anggota & 2 & 9 & 8 & 2 & 0 & 3.52 \\
2 & Mampu memberikan contoh teladan & 2 & 10 & 8 & 1 & 0 & 3.62 \\
3 & Mampu membuat acara rutinitas & 9 & 9 & 2 & 1 & 0 & 4.24 \\
4 & Memberikan penilaian dan penghargaan & 3 & 7 & 8 & 3 & 0 & 3.48 \\
5 & Mampu menguasai pekerjaan & 4 & 5 & 9 & 3 & 0 & 3.48 \\
6 & Senang bekerja & 4 & 14 & 3 & 0 & 0 & 4.05 \\
7 & Kepatuhan bekerja & 4 & 9 & 8 & 0 & 0 & 3.81 \\
8 & Kemauan menyelesaikan pekerjaan & 3 & 7 & 8 & 3 & 0 & 3.48 \\
9 & Kesungguhan dalam bekerja & 4 & 5 & 9 & 3 & 0 & 3.48 \\
& Rata-rata Skor & & & & & & $\mathbf{3 . 6 8}$ \\
\hline
\end{tabular}

Sumber : Data primer yang diolah, 2014

Berdasarkan tabel 4.2 diatas diketahui bahwa skor jawaban responden untuk variabel harga adalah 3.68 berada pada kategori cukup baik $(3,00-4,00)$. Hal ini mengindikasikan bahwa etos kerja karyawan berada pada keadaan yang cukup baik
Variabel Pelayanan Akademik (Y)

Analisis kualitatif untuk pengukuran variabel Kualitas Pelayanan dapat dilihat pada Tabel berikut :

Tabel Tanggapan Responden Terhadap Variabel Kualitas Pelayanan

\begin{tabular}{|c|c|c|c|c|c|c|c|}
\hline No & Indikator & $\mathrm{SS}$ & $\mathrm{S}$ & $\mathrm{CS}$ & $\mathrm{TS}$ & STS & Skor \\
\hline 1 & Ruang Parkir sudah layak & 18 & 34 & 22 & 6 & $\mathbf{0}$ & 3.80 \\
\hline 2 & Gedung Kampus sudag layak & 23 & 36 & 17 & 3 & 1 & 3.96 \\
\hline 3 & Kelas sudah layak & 18 & 33 & 26 & 2 & 1 & 3.81 \\
\hline 4 & Fasiltas kelas/peralatan sudah layak & 14 & 40 & 24 & 2 & 0 & 3.83 \\
\hline 5 & Lab sudah layak & 14 & 38 & 26 & 1 & 1 & 3.79 \\
\hline 6 & Perpustakaan sudah layak & 13 & 32 & 33 & 2 & 0 & 3.70 \\
\hline 7 & Mushola sudah layak & 10 & 33 & 35 & 2 & 0 & 3.64 \\
\hline 8 & Kantin sudah layak & 21 & 42 & 17 & 0 & 0 & 4.05 \\
\hline 9 & Toiet sudah layak & 21 & 39 & 20 & 0 & 0 & 4.01 \\
\hline 10 & Tempat duduk/ruang tunggu sudah layak & 16 & 41 & 20 & 3 & 0 & 3.88 \\
\hline \multirow[t]{2}{*}{11} & Kualitas Kemampuan (kompetensi) Dosen & & & & & & \\
\hline & Dalam Penyampaian Materi Kuliah sudah layak. & 26 & 33 & 20 & 1 & 1 & 4.06 \\
\hline 12 & $\begin{array}{l}\text { Kualitas kemampuan (kompetensi) karyawan } \\
\text { sudah layak }\end{array}$ & 24 & 35 & 19 & 1 & 0 & 3.99 \\
\hline 13 & $\begin{array}{l}\text { Kecepatan karyawan dalam merespon keluhan } \\
\text { mahasiswa Sudah layak }\end{array}$ & 18 & 34 & 22 & 6 & 1 & 3.81 \\
\hline 14 & $\begin{array}{lll}\text { Kecepatan/kesigapan } & \text { Karyawan } & \text { dalam } \\
\text { Pelayanan administrasi } & \text { kemahsiswaan } & \text { sudah } \\
\text { layak } & & \end{array}$ & 23 & 36 & 17 & 3 & 1 & 3.96 \\
\hline 15 & $\begin{array}{l}\text { Kemananan fisik (lingkungan kampus), } \\
\text { financial dan Kerahasiaan sudah layak }\end{array}$ & 18 & 33 & 26 & 2 & 0 & 3.80 \\
\hline 16 & Kredibilitas Dosen sudah layak & 14 & 40 & 24 & 2 & 1 & 3.84 \\
\hline 17 & Kredibilitas manajemen pendidikan sudah layak & 14 & 38 & 26 & 1 & 0 & 3.78 \\
\hline 18 & $\begin{array}{l}\text { Kredibilitas Pengetahuan dan keterampilan } \\
\text { Karyawan dalam Pelayanan sudah layak }\end{array}$ & 13 & 32 & 33 & 2 & 0 & 3.70 \\
\hline 19 & Reputasi Lembaga sudah layak & 10 & 33 & 35 & 2 & 0 & 3.64 \\
\hline 20 & Komunikasi Pelayanan sudak baik & 21 & 42 & 17 & 0 & 0 & 4.05 \\
\hline 21 & Pemahaman Kebutuhan Pelanggan sudah baik & 21 & 39 & 20 & 0 & 0 & 4.01 \\
\hline 22 & Keramahan, Perhatian, Sopan santun Dan & 16 & 41 & 20 & 3 & 0 & 3.88 \\
\hline
\end{tabular}




\begin{tabular}{|c|c|c|c|c|c|c|c|}
\hline No & Indikator & SS & $\mathrm{S}$ & $\mathrm{CS}$ & TS & STS & Skor \\
\hline & Respek Karyawan sudah baik & & & & & & \\
\hline & Rata-rata skor & & & & & & 3,86 \\
\hline
\end{tabular}

\section{Sumber : Data primer yang diolah, 2014}

Berdasarkan tabel 4.3 diatas diketahui bahwa skor jawaban responden untuk variabel kualitas pelayanan adalah 3.86 berada pada kategori tidak setuju $(3,00-4,00)$. Hal ini mengindikasikan bahwa kualitas pelayanan yang diberikan kepada mahasiswa cukup baik

\section{Analisis Kuantitatif}

Uji Asumsi Klasik

Uji Multikolinearitas

Uji multikolinearitas bertujuan untuk menguji apakah pada model regresi ditemukan adanya korelasi antar variabel independen. Jika terjadi korelasi, maka dinamakan terdapat problem Multikolinearitas. Model regresi yang baik seharusnya tidak terjadi korelasi di antara variabel independen.

Deteksi tidak adanya Multikolinearitas yakni dengan melihat besaran VIF (Variance Inflation Factor) dan Tolerance (Ghozali, 2006): a. Mempunyai nilai VIF < 10; b) Mempunyai angka TOLERANCE $>10 \%$.

Mengacu pada kedua pendapat di atas maka berdasarkan hasil penelitian yang telah dilakukan dapat diperoleh nilai :

\section{Tabel 15. Tabel Hasil Uji Multikolinearitas}

Pengecekan Multikolinearitas

\begin{tabular}{llll}
\hline & & \multicolumn{2}{l}{ Collinearity Statistics } \\
Model & & Tolerance & VIF \\
\hline 1 & (Constant) & & \\
& Budaya Organisasi & .432 & 2.235 \\
& Etos Kerja & .427 & 2.242 \\
\hline
\end{tabular}

Sumber : data Primer yang Diolah, 2014

Berdasarkan hasil tersebut maka dalam model regresi tidak terjadi multikolinearitas atau korelasi yang sempurna antara variabel-variabel bebas, yaitu budaya organisasi dam etos kerja, karena IF lebih kecil dari 10 dan nilai tolerance lebih besar dari 0,1 .

\section{Uji Heteroskedastisitas}

Heteroskedastisitas terjadi apabila tidak ada kesamaan deviasi standar nilai variabel dependen pada setiap variabel independen. Deteksi dengan melihat ada tidaknya pola tertentu pada grafik berikut ini gambar 9:

Dari grafik tersebut, dapat terlihat titiktitik yang menyebar secara acak, tidak membentuk suatu pola tertentu yang jelas, serta tersebar baik di atas maupun di bawah angka 0 (nol) pada sumbu Y, maka tidak terjadi heteroskedastisitas.

\section{Uji Normalitas}

Uji normalitas bertujuan untuk menguji apakah dalam model regresi, variabel terikat dan variabel bebas atau keduanya mempunyai distribusi normal atau tidak. Model regresi yang baik adalah memiliki distribusi data normal atau mendekati normal. Deteksi dengan melihat penyebaran data (titik) pada sumbu diagonal dari grafik. Dasar pengambilan keputusan: a. Jika data menyebar disekitar garis diagonal dan mengikuti arah garis diagonal, maka model regresi memenuhi asumsi normalitas; dan b) Jika data menyebar jauh dari garis diagonal dan tidak mengikuti arah garis diagonal, maka model regresi tidak memenuhi asumsi normalitas. 
Yunita Indriany , Pengaruh Budaya Organisasi Dan Etos Kerja ...

\section{Gambar 9. Pengujian Heteroskedastisitas \\ Scatterplot}
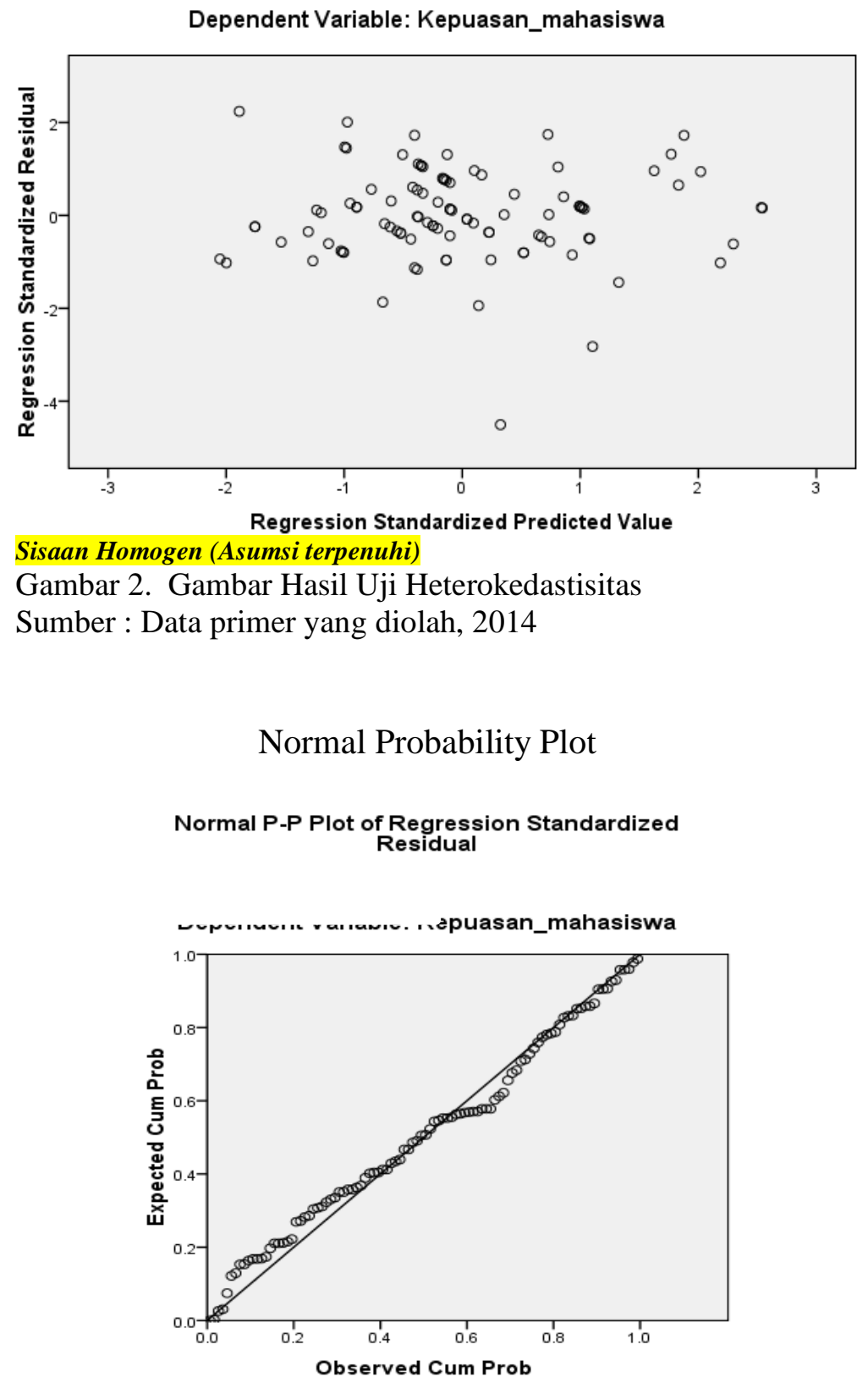

Normalitas (Sisaan menyebar normal: Asumsi Terpenuhi)

Gambar 3. Hasil Pengujian Normalitas

Sumber : Data primer yang diolah, 2014

Berdasarkan hasil analisis data dengan menggunakan SPSS, maka dapat diketahui bahwa data menyebar disekitar garis diagonal dan mengikuti arah garis diagonal, maka model regresi memenuhi asumsi normalitas.

\section{Analisis Regresi Linier Berganda}

Berdasarkan perhitungan regresi berganda antara budaya organisasi (X1), etos kerja (X2) terhadap kualitas pelayanan (Y) dengan dibantu program SPSS dalam perhitungannya dapat diperoleh hasil sebagai berikut 
Majalah Ilmiah Ilmu Administrasi

ISSN 1411-0830

Tabel Tabel Ringkasan Hasil Estimasi Regresi

\begin{tabular}{lllllll}
\hline \multicolumn{2}{c}{} & & \multicolumn{5}{l}{ Standardized } \\
Model & & $\mathrm{B}$ & Std. Error & Beta & T & Sig. \\
\hline 1 & (Constant) & .457 & .298 & & 1.625 & .107 \\
& Budaya_organisasi & .035 & .017 & .101 & 1.714 & .000 \\
& NEtos_Kerja & .678 & .076 & .757 & 9.087 & .000 \\
\hline
\end{tabular}

Sumber : Data primer yang diolah, 2014

Berdasarkan tabel di atas, maka persamaan regresi yang terbentuk pada uji regresi ini adalah

\section{$\mathrm{Y}=0.457+0.025 \mathrm{X} 1+0.678 \mathrm{X} 2$.}

Berdasarkan persamaan dapat diketahui bahwa: a). Nilai koefisien regresi variabel budaya organisasi sebesar 0,025 bernilai positif mempunyai arti bahwa jika persepsi terhadap budaya organisasi semakin baik, maka kualitas pelayanan akan meningkat; b). Nilai koefisien regresi variabel etos kerja sebesar 0.678 bernilai positif mempunyai arti bahwa jika persepsi terhadap etos kerja semakin baik, maka kualitas pelayanan akan meningkat.

\section{Pengujian Hipotesis}

Uji t

Uji t ini digunakan untuk mengetahui ada atau tidaknya pengaruh antara budaya organisasi (X1) dan etos kerja (X2) terhadap kualitas pelayanan (Y) secara parsial.

Perumusan hipotesis

$\mathrm{H} 0: \beta<0$ : tidak ada pengaruh yang positif dan signifikan antara budaya organisasi (X1) dan etos kerja (X2) terhadap kualitas pelayanan (Y)

Ha $: \beta>0 \quad$ : ada pengaruh yang positif dan signifikan antara budaya organisasi (X1) dan etos kerja (X2) terhadap kualitas pelayanan (Y)

Melalui perhitungan dengan menggunakan program SPSS dapat diketahui sebagai berikut: a). Budaya Organisasi Mempunyai Pengaruh Yang Positif Terhadap Kualitas Pelayanan, Dari hasil perhitungan diperoleh nilai t hitung untuk variabel kualitas pelayanan adalah sebesar 1,728 dan dengan menggunakan level significance (taraf signifikasi) sebesar 5\% diperoleh $\mathrm{t}$ tabel sebesar 1,661 yang berarti bahwa nilai $t$ hitung lebih besar dari t tabel yaitu $1,728>1,661$. Nilai signifikasi t kurang dari $5 \%$ $(0,000)$, menandakan bahwa budaya organisasi (X1) mempunyai pengaruh yang positif dan signifikan terhadap kualitas pelayanan (Y). Dengan demikian dapat disimpulkan bahwa Ho ditolak dan H1 diterima, sehingga hipotesis yang menyatakan budaya organisasi mempunyai pengaruh yang positif terhadap kualitas pelayanan dapat diterima; b). Etos Kerja Mempunyai Pengaruh Yang Positif Terhadap Kualitas Pelayanan, Dari hasil perhitungan diperoleh nilai $t$ hitung untuk variabel harga adalah sebesar 8.725 dan dengan menggunakan level significance (taraf signifikasi) sebesar 5\% diperoleh $\mathrm{t}$ tabel sebesar 1,661 yang berarti bahwa nilai t hitung lebih besar dari t tabel yaitu $8.725>1,661$. Nilai signifikasi t kurang dari $5 \%$ $(0,000)$, menandakan bahwa etos kerja (X2) mempunyai pengaruh yang positif dan signifikan terhadap kualitas pelayanan (Y). Dengan demikian dapat disimpulkan bahwa Ho ditolak dan H2 diterima, sehingga hipotesis yang menyatakan etos kerja mempunyai pengaruh yang positif terhadap kualitas pelayanan dapat diterima.

\section{Uji F}

Dalam melakukan uji $\mathrm{F}$, parameter yang digunakan adalah dengan membandingkan Fhitung > F-tabel. Pengujian terhadap pengaruh variabel bebas terhadap variabel terikat secara simultan dilakukan dengan uji $\mathrm{F}$ dengan hasil yang dapat dilihat pada tabel 4.7 berikut ini. 
Yunita Indriany, Pengaruh Budaya Organisasi Dan Etos Kerja ...

\section{ANOEVA}

\begin{tabular}{llllll} 
ANOVA $^{\mathbf{b}}$ & \multicolumn{5}{l}{} \\
\hline Model & Sum of Squares & Df & Mean Square & F & Sig. \\
\hline 1Regression & 42.766 & 2 & 21.383 & 111.520 & $.000^{\mathrm{a}}$ \\
Residual & 18.599 & 97 & .192 & & \\
Total & 61.365 & 99 & & &
\end{tabular}

a. Predictors: (Constant), budaya_organisasi, Ktos_kerja

b. Dependent Variable: Kualitas_Pelayanan

Sumber : Data primer yang diolah 2014

Berdasarkan tabel 4.7. menunjukkan hasil perhitungan uji $\mathrm{F}$ diperoleh nilai F-hitung sebesar 111.520 dengan tingkat signifikansi sebesar $0,000(<0,05)$. Sementara nilai F-tabel sebesar 2,70 (dari perhitungan $\mathrm{dk} 1=2$, alpha $=0,05$ dan $\mathrm{dk}=80-2-1=77$ diperoleh $\mathrm{F}$ table 2.70). Ini berarti bahwa F-hitung $(111.520)>$ Ftabel (2.70) dengan demikian Ho ditolak dan H1 diterima, artinya bahwa budaya organisasi dan etos kerja berpengaruh secara simultan atau bersama-sama terhadap kualitas pelayanan.

\section{Korelasi Product Moment (Korelasi dan Determinasi)}

Menurut Sugiyono (2009; 228), Korelasi Product Moment merupakan suatu Teknik korelasi yang digunakan untuk mencari hubungan dan membuktikan hipotesis hubungan dua variable bila data kedua variable berbentul interval atau ratio, dan sumber data dari dua variable atau lebih tersebut adalah sama.

Berikut ini dikemukakan rumus yang paling sederhana yang dapat digunakan untuk menghitung koefesien korelasi adalah sebagai berikut :

$$
r_{x y}=\frac{n \sum x y-\left(\sum x\right)\left(\sum y\right)}{\sqrt{\left.\left(n \sum x^{2}-\left(\sum x\right)^{2}\right)\left(n \sum y^{2}\right)-\left(\sum y\right)^{2}\right)}}
$$

Dimana :

rxy $=$ Korelasi antara variable $\mathrm{x}$ dengan $\mathrm{y}$

$\mathrm{x}=$ variable $\mathrm{x}_{-}^{-}$

$\mathrm{x}=$ variable $\mathrm{y}^{-}$

\section{Korelasi Hubungan antara Budaya Organisasi} dengan Kualitas Pelayanan

Tabel Model Summary Koefisien Determinasi

\begin{tabular}{lllll}
\multicolumn{5}{c}{ Model Summary $^{\mathbf{b}}$} \\
\begin{tabular}{lllll} 
Model & $\mathrm{R}$ & R Square & Adjusted R Square & Std. Error of the Estimate \\
\hline 1 & $.663^{\mathrm{a}}$ & .439 & .431 & .34253 \\
\hline a. Predictors: (Constant), Buadaya_Organisasi & & \\
b. Dependent Variable: Kualitas_Pelayanan & &
\end{tabular}
\end{tabular}

Sumber : Data Primer yang Diolah, 2014

Berdasarkan data table di atas dapat diketahui bahwa besarnya nilai koefisien korelasi antara Budaya Organisasi dan Kualitas Pelayanan ditunjukkan oleh nilai $r$ sebesar 0.663 yang berarti hubungan diantara keduanya kuat.
Sedangkan nilai Koefesien Determinasi $\left(\mathrm{R}^{2}\right)$ adalah sebesar 0,439 yang artinya bahwa Budaya Organisasi dapat menerangkan variabel Kualitas Pelayanan sebesar 43,9 \%, sedangkan sisanya sebesar $56,1 \%$ diterangkan oleh variabel lain yang tidak diajukan dalam penelitian ini. 


\section{Korelasi Hubungan antara Etos Kerja dengan Kualitas Pelayanan}

Tabel Model Summary Koefisien Determinasi

\begin{tabular}{lllll}
\multicolumn{4}{c}{ Model Summary $^{\mathbf{b}}$} & \\
\hline Model & $\mathrm{R}$ & $\mathrm{R}$ Square & Adjusted R Square & Std. Error of the Estimate \\
\hline 1 & $.832^{\mathrm{a}}$ & .692 & .691 & .43362 \\
\hline a. Predictors: (Constant), Etos_Kerja & & \\
b. Dependent Variable: Kualitas Pelayanan & &
\end{tabular}

Sumber : Data Primer yang Diolah, 2014

Berdasarkan data table di atas dapat diketahui bahwa besarnya nilai koefisien korelasi antara Etos Kerja dan Kualitas Pelayanan ditunjukkan oleh nilai $\mathrm{r}$ sebesar 0.832 yang berarti hubungan diantara keduanya sangat kuat. Sedangkan nilai Koefesien Determinasi $\left(\mathrm{R}^{2}\right)$ adalah sebesar 0,692 yang artinya bahwa etos kerja dapat menerangkan variabel kualitas pelayanan sebesar $69,2 \%$, sedangkan sisanya sebesar 30,8\% diterangkan oleh variabel lain yang tidak diajukan dalam penelitian ini.

\section{Koefisien Determinasi antara Budaya Organisasi dan Etos Kerja dengan Kualitas Pelayanan}

Untuk mengetahui besarnya pengaruh budaya organisasi dan etos kerja terhadap kualitas pelayanan dapat dilihat dari besarnya nilai adjusted $\mathrm{R}^{2}$

Tabel Model Summary Koefisien Determinasi Model Summary ${ }^{\text {b }}$

\begin{tabular}{lllll}
\hline Model & $\mathrm{R}$ & $\mathrm{R}$ Square & Adjusted R Square & Std. Error of the Estimate \\
\hline 1 & $.835^{\mathrm{a}}$ & .697 & .691 & .43788 \\
\hline
\end{tabular}

a. Predictors: (Constant), Budaya_Organisasi, Etos_Kerja

b. Dependent Variable: Kualitas_Pelayanan

Sumber : Data Primer yang Diolah, 2014

Berdasarkan tabel di atas, dapat diketahui bahwa besarnya nilai koefisien determinasi ditunjukkan oleh nilai $\mathrm{R}$ Square yaitu sebesar 0.697 yang artinya bahwa variasi dari semua variabel bebas yaitu budaya organisasi dan etos kerja dapat menerangkan variabel kualitas pelayanan sebesar $69.7 \%$, sedangkan sisanya sebesar 30,3\% diterangkan oleh variabel lain yang tidak diajukan dalam penelitian ini.

\section{Pembahasan}

\section{Pembahasan Hasil Penelitian}

Dengan melibatkan sebanyak 80 orang responden mahasiswa dan 21 orang karyawan, memberikan informasi mengenai pengaruh dari variabel budaya organisasi dan etos kerja terhadap kualitas pelayanan

Dari tabel tersebut dapat diterangkan bahwa angka $\mathrm{R}$ square sebesar 0.697 yang artinya bahwa variasi dari semua variabel bebas yaitu budaya organisasi dan etos kerja dapat menerangkan variabel kualitas pelayanan sebesar $69.7 \%$, sedangkan sisanya sebesar 30,3\% diterangkan oleh variabel lain yang tidak diajukan dalam penelitian ini.

Dari tabel uji validitas dapat diketahui bahwa variabel budaya organisasi dan etos kerja serta kualitas pelayanan mempunyai $\mathrm{r}$ hitung yang lebih besar daripada $r$ kritis 0,3 , sehingga dapat dikatakan bahwa semua indikator pertanyaan yang digunakan dalam penelitian ini adalah valid. 
Yunita Indriany, Pengaruh Budaya Organisasi Dan Etos Kerja ...

Dari tabel uji reliabilitas dapat diketahui bahwa masing-masing variabel antara budaya organisasi, etos kerja dan kualitas pelayanandiperoleh nilai Cronbach Alpha $\geq 0,60$. Dengan demikian, maka hasil uji reabilitas terhadap keseluruhan variabel adalah reliabel.

Dari gambar grafik distribusi normalitas menunjukkan bahwa titik-titik menyebar di sekitar garis diagonal dan mengikuti arah garis diagonal. Dengan demikian menunjukan pola distribusi yang normal, maka model regresi memenuhi asumsi normalitas. Dari tabel multikolinearitas dapat diketahui bahwa nilai Variance Inflation Factor ( VIF ) dari masing masing variabel bebas lebih kecil dari angka 10, dan nilai tolerance lebih besar dari 0,1 . Sehingga dapat disimpulkan bahwa pada uji regresi tersebut tidak terdapat problem multikolinieritas, maka model yang ada layak untuk dipakai.

Dari gambar heteroskedastisitas terdeteksi titik-titik yang ada adalah menyebar, dan tidak membentuk pola tertentu, sehingga tidak terjadi heteroskedastisitas.

Dari uji t diketahui bahwa nilai t hitung > $\mathrm{t}$ tabel dan tingkat signifikan $<0,05$ hanya untuk variabel budaya organisasi. Sehingga dapat disimpulkan bahwa variabel budaya organisasi dan etos kerja secara parsial berpengaruh terhadap kualitas pelayanan

Dari uji F juga di ketahui bahwa F hitung $>\mathrm{F}$ tabel dan tingkat signifikasi $<0,05$ sehingga dapat disimpulkan bahwa variabel budaya organisasi dan etos kerja secara bersama-sama berpengaruh terhadap kualitas pelayanan.

\section{Pembahasan Implementasi Hasil Penelitian}

Berdasarkan hasil penelitian di atas, terlihat bahwa korelasi (kaitan) antara budaya organisasi dan etos kerja dengan kualitas pelayanan terlihat memiliki pengaruh yang kuat. Hal tersebut ditunjukkan dengan nilai koefisien korelasi sebesar 0.835. Adapun kontribusi budaya organisasi dan etos kerja terhadap kualitas pelayanan memiliki prosentase yang sangat besar. Hal tersebut ditunjukkan oleh koefisien determinasi sebesar $69.7 \%$.

Masih dari hasil penelitian, secara umum dapat disimpulkan bahwa mahasiswa sudah cukup puas terhadap semua komponen pelayanan yang diberikan lembaga, baik itu yang menyangkut pelayanan yang bersifat tangible, realibility, Responsivness, Assurance maupun Empaty, dimana nilai dalam skala likert yang ada sudah menunjukkan besarannya di atas 3 atau cukup memuaskan.

Namun meskipun demikian hasil di atas belum menunjukkan hasil yang maksimal, dan ini tentunya ini haruslah menjadi perhatian lembaga agar mampu mengapresiasi sekaligus mengakomodir keluhan mahasiswa yang bersangkutan dalam bentuk perbaikan upaya pelayanan yang jauh lebih baik lagi ke depan.

Dari data di atas jelaslah sudah bahwa peranan budaya organisasi dan etos kerja merupakan variable yang berpengaruh dan menentukan dalam mempengaruhi tingkat kualitas pelayanan, karena maju mundurnya suatu lembaga pendidikan bermula dari tingkat kepuasan mahasiswa. Semakin tinggi tingkat kepuasan mahasiswa, semakin besar peluang lembaga untuk menjaga eksistensi dan pengembangan program pendidikannya ke depan.

Kita mengetahui bahwa kehadiran persaingan pendidikan di antara perguruan tinggi berjalan sangat ketat, sehinga disadari atau tidak, langsung maupun tidak langsung, tingkat kepuasan mahasiswa ini akan menjadi faktor yang sangat menentukan dalam memilih perguruan tinggi mana yang akan mereka pilih.

Faktor tersebut haruslah disikapi dengan bijak oleh setiap perguruan tinggi, karena fenomena tersebut merupakan sebuah proses rangkaian sebab akibat yang tidak dapat dibendung dan merupakan suatu keniscayaan yang harus kita hadapi dan sikapi dengan bijak dan positif, agar kita mampu menyelaraskan ritme dan irama gelombang perubahan serta tidak tergilas oleh perkembangan jaman.

Karena disadari atau tidak, setiap Perguruan Tinggi senantiasa berusaha semaksimal mungkin untuk menjaring perolehan jumlah mahasiswa sebanyak-banyaknya. Berbagai upaya dilakukan melalui promosi untuk menjaring minat konsumen baik dari sisi penawaran program pendidikan yang sesuai dengan tuntutan dan perkembangan jaman, pelayanan pendidikan yang memuaskan, harga jual yang sangat terjangkau, pengadaan fasilitas, 
sarana dan prasarana yang mendukung, dosendosen yang kualified, serta berbagai tawaran kemudahan dan kepuasan lainnya.

Persaingan bisnis pendidikan jelas tak terhindarkan, dan akan membawa dampak konsekuensi yang sangat logis apakah ia mampu akan mampu bertahan, maju dan berkembang atau sebaliknya menjadi perguruan tinggi yang tidak atau kurang berkualitas, tidak diminati, kalah bersaing dan akhirnya hancur (tutup).

Situasi persaingan yang ketat dari waktu ke waktu, menyebabkan banyak perguruan tinggi, khususnya perguruan tinggi swasta sulit untuk meningkatkan jumlah mahasiswanya, sehingga dengan demikian semakin sulit mempertahankan eksistensinya.

Oleh karena itu, lembaga perguruan tinggi harus mampu membangun suatu konsep untuk menunjang kualitas pelayanan melalui pendekatan kelembagaan dalam hal ini membangun budaya organisasi yang lebih kondusif untuk meningkatkatkan kualitas kelembagaan serta membangun etos kerja/semangat karyawannya agar sejalan dengan semangat untuk membangun kualitas pelayanan yang baik.

Budaya organisasi serta etos kerja yang baik, akan mampu membangun kualitas pelayanan yang sejalan dengan kebutuhan mahasiswa dan mampu menjadi ekternal marketing bagi calon mahasiswa yang lain untuk mengajak kuliah di lembaga tersebut.

Politeknik LP3I Jakata, kampus Cibinong, harus memiliki tujuan tersebut jika memang ingin membangun suatu lembaga yang berkualitas, agar ia tetap eksis, maju dan berkembang seiring kemajuan jaman.

\section{Kesimpulan}

Berdasarkan hasil analisis data yang telah dilakukan terhadap seluruh data yang diperoleh, maka dapat diambil kesimpulan sebagai berikut: a). Budaya Organisasi secara parsial berpengaruh positif terhadap kualitas pelayanan yang ditunjukkan oleh nilai $r$ sebesar 0.663 yang berarti hubungan diantara keduanya cukup kuat. Sedangkan nilai koefisien determinasi $\left(\mathrm{R}^{2}\right)$ adalah sebesar 0.439 yang berarti bahwa budaya organisasi dapat menerangkan variabel kualitas pelayanan sebesar $43.9 \%$, sedangkan sisanya sebesar $46.1 \%$ diterangkan oleh variabel lain; b) Etos kerja secara parsial berpengaruh positif terhadap kualitas pelayanan yang ditunjukkan oleh nilai $r$ sebesar 0.832 yang berarti hubungan diantara keduanya cukup kuat. Sedangkan nilai koefisien determinasi $\left(\mathrm{R}^{2}\right)$ adalah sebesar 0,692 yang berarti bahwa etos kerja dapat menerangkan variabel kualitas pelayanan sebesar $69.2 \%$, sedangkan sisanya sebesar 30,8\% diterangkan oleh variabel lain; c) Secara simultan variabel budaya organisasi dan etos kerja memiliki pengaruh yang signifikan terhadap kualitas pelayanan yang ditunjukkan oleh nilai $r$ sebesar 0.835 yang berarti hubungan diantara keduanya kuat. Sedangkan nilai koefisien determinasi $\left(\mathrm{R}^{2}\right)$ adalah sebesar 0.69.7 yang berarti bahwa budaya organisasi dan etos kerja dapat menerangkan variabel kualitas pelayanan sebesar $69.7 \%$, sedangkan sisanya sebesar $30,3 \%$ diterangkan oleh variabel lain.

\section{Saran}

Berdasarkan kesimpulan yang telah dikemukakan, maka diberikan beberapa saran yang diharapkan dapat meningkatkan kualitas pelayanan di Politeknik LP3I Jakarta yang diberikan oleh Manajemen Kampus Cibinong adalah dengan cara meningkatkan point-point nilai yang di bawah rata-rata yaitu sebagai berikut: 1. Kualitas pelayanan: 1.a) Mampu menumbuhkan budaya untuk senantiasa berorientasi kepada hasil dan tim; 1.b). Membuat acara rutinitas; dan 1.c). Memberikan penilaian dan penghargaan; 2. Variabel Etos Kerja (X2): 2.a). Mampu melakukan pembinaan; 2.b). Mampu memberikan contoh teladan; 2.c). Memberikan penilaian dan penghargaan; 2.d). Mampu menguasai pekerjaan; 2.e). Kemauan menyelesaikan pekerjaan;dan 2.f).Kesungguhan dalam bekerja; 3. Kualitas Pelayanan: 3.a). Kelayakan kelas; 3.b). Kelayakan fasiltas kelas/peralatan; 3.c). Kelayakan Lab; 3.d). Kelayakan perpustakaan; 3.e). Kelayakan mushola; 3.f). Kecepatan karyawan dalam 
Yunita Indriany, Pengaruh Budaya Organisasi Dan Etos Kerja ...

merespon keluhan mahasiswa; 3.g). Kemananan fisik (lingkungan kampus), financial dan kerahasiaan: 3.h). Kredibilitas Dosen; 3.i). Kredibilitas manajemen pendidikan; 3.j). Kredibilitas Pengetahuan dan keterampilan Karyawan dalam Pelayanan; dan 3.k). Reputasi Lembaga.

\section{DAFTAR PUSTAKA}

Aryotedjo, 2005, "Pengaruh Kualitas Jasa, Kepuasan dan Komitmen Pelanggan Terhadap Loyalitas Konsumen Pada Bisnis Retail”, Jurnal Bisnis dan Manajemen, Vol. 5, No. 2: 223-232.

Atmosoeprapto, K., 001. Produktivitas Aktualisasi Budaya Perusahaan, Jakarta, Gramedia.

Chandra, Filicia dan Theresia Widyaratna Danny, 2001, "Analisis Kepuasan dan Loyalitas Konsumen Terhadap Tingkat Penjualan di Warung Bu Kris", Jurnal Manajemen dan kewirausahaan, vol. 3, Vol. 2: 85-95.

Fariza, Diana, 2008, “Analisis Faktor-Faktor yang mempengaruhi Kepuasan Pelanggan Terhadap Kepuasan Pelanggan GSM Indosat di Kota Semarang",

Hofstede, Geert, 1997, Culture's and Organization, New York, Washington D.C London, Me Craw-Hill, hal.9

Korter , Jhon P, and James L. Hesket, 1992, Corporate Culture and Performance, New York, Maxwell, Macmillan, Canada, Inc.

Kotter, J.P. Heskett S.L. 1997, Corporate Culture and Performance, Alih bahasa Benyamin Molan.

McNamara, Clayton, 1999, Organizational Culture, Oxford University Press, Oxford.

Moelyono, Djokosantoso, 2005. Cultured, Budaya Organisasi dalam Tantangan, Jakarta, PT Elex Media Komputindo.
Paul dan Kenneth H. Blanchard. 1995. Manajemen Perilaku Organisasi : Pendayagunaan Sumber Daya Manusia. Terjemahan Agus Dharma. Jakarta. Erlangga Paramita,Jakarta,Cet.II,2007.

Pheysey, Diana C., 1993, Organization Cultures : Types and Transformations, Routledge, New York.

Samhadi, Sri Hartati, "Etos kerja Indonesia terburuk di Asia? http://trainingethos.

Tika, Moh. Pabundu, 2006. Budaya Organisasi dan Peningkatan Kinerja Perusahaan. Jakrta, Bumi Aksara.

Triguno. 1997. Budaya Kerja, Menciptakan Lingkungan yang Kondusif untuk Meningkatkan Produktivitas Kerja. PT. Golden Teravon Press. Jakarta

Umar, Husen, 1999. Riset Sumber Daya Manusia dalam Organisasi, Jakarta PT Gramedia.

Indriantoro, Nur dan Bambang Supomo, 1999, Metodologi Penelitian Bisnis, Yogyakarta: BPFE.

I Made Bayu Dirgantara, 2006, "Pengaruh Kualitas Pelayanan Dalam Tingkat Kepuasan Konsumen Produk Jasa”, Jurnal Bisnis Strategi, Vol. 15, No. 2.

Kotler, Philip, 1997, Marketing Management: Analysis, Planning, Implementation, and Control, 9th Ed., Englewood Cliffs, NJ: Prentice Hall, Inc.

Sugiyono, 2004, Metode Penelitian Bisnis, Alfabetha, Bandung.

Tim Penyusun Pedoman Penulisan Tesis Program Pasca Sarjana Ilmu Administrasi STIAMI. 2012. Pedoman Penulisan Tesis dan artikel Ilmiah Program Pasca Sarajana Ilmu administrasi. Jakarta 


\section{BIJAK}

Majalah Ilmiah Ilmu Administrasi

ISSN 1411-0830

Tjiptono, Fandy dan Gregorius Chandra, 2005,
Volume XIII, No. 02, September 2016
Service, Quality and Satisfaction, Yogyakarta: ANDI. Yogyakarta: ANDI.
Widiyanto, Ibnu, 2008, Pointers: Metodologi Penelitian, Semarang: Badan Penerbit Universitas Diponegoro. 